\title{
RECONSTRUCTION OF BONDS ARRANGEMENTS IN INDONESIAN CAPITAL MARKET JUSTICE-BASED VALUE
}

\author{
Elvira Fitriani Pakpahan \\ Prima University Indonesia, Medan \\ elvirapakpahans3@gmail.com
}

\begin{abstract}
Trustee contracts referring to the special provisions on guarantees stipulated by Bapepam(Capital Market Supervisory Agency)/OJK (Financial Service Authority) as referred in item 4 letter E Kep. Bapepam-LK No.412 / BL / 2010 are considered too general. The provision of guarantee on number 4 letter E Kep.Bapepam No.412 is limited to informational provisions, not a requirement. The purpose of this paper is to know and analyze the implementation of bond arrangements and weaknesses in the capital market of Indonesia based on the value of justice. This research used sociological juridical method. The primary data based on field research, secondary data from reference and law. Based on the results of research implementation of bond arrangement in Indonesia capital market does not give justice value to the parties such as issuer, trustee and investor in particular. Unclear arrangements in Bapepam-LK's Decree on General Provisions and Trustee Contracts under the Warranty (if any) do not provide legal certainty and fairness to bond investors in the event of default. The weaknesses in the implementation of bonds arrangement in the Indonesian capital market due to the functions and duties of the Trustee listed in UUPM have no regulatory arrangements, as well as the absence of guidelines/standards in the preparation of the trustee contract. The reconstruction of the law shall be conducted by changing the special provisions of Bapepam Decree Number 412 on item 4 letter $E$ concerning the guarantee (if any) by removing / removing the existing word in parentheses (if any), as it does not reflect the value of legal certainty and dignified justice.
\end{abstract}

Keywords : investment, sukuk, banking law, Legal Guarantee, bonds 


\section{A. Introduction}

In order to realize a just and prosperous society in accordance with the ideals and national goals based on Pancasila and the 1945 Constitution of the State of the Republic of Indonesia, it is necessary to increase the ability and independence to carry out national economic development on a sustainable basis on the strength of society. Indonesia's economic development mandated by the constitution must be implemented with all the potential that exists in society. Article 33 Paragraph (4) of the amended 1945 Constitution states that the national economy is organized on the basis of economic democracy with the principle of togetherness, environmental insight, independence, and by maintaining a balance of progress and national economic unity.

The development of a country requires a huge amount of funding. The implementation is prioritized on the utilization of domestic funding sources, while foreign loan funds as supporters. Sources of foreign loan funds are not always reliable for development, therefore there needs to be serious efforts to create an investment climate. Investment climate can encourage economic growth of a country. ${ }^{1}$

Investment funds are not only utilized by the government sector, but also the private sector. Governments typically act as initiators of physical infrastructure development, while private parties (individuals / corporations) act as drivers of commercial economic activity. All of these require short-term investment funds such as working capital for

\footnotetext{
${ }^{1}$ Panji Anoraga \& Ninik Widiyanti, Pasar Modal; Keberadaan dan Manfaatnya bagi Pembangunan, (Jakarta:RinekaCipta, 1995), page 2.
} 
operational cost, as well as long-term costs such as for the acquisition of required fixed assets. ${ }^{2}$

The current investment alternatives are money market and capital market. Money markets and capital markets are both part of the financial market which is a means of driving funds or a place to bring together the excess funds and those who are underfunded and formed to facilitate the exchange of money between savers and borrowers ${ }^{3}$. The essence of these two markets is basically as an intermediary of the process of delivering funds from an individual or institution that has a supplier of funds to a user of fund and uses it for productive activities both for short, Medium, and long term. ${ }^{4}$

Stock and bonds are the two most popular securities in the Capital Market. Stock and bonds have differences, seen from the definition and rights of the holders of such securities. Shares are securities that have the character of an investment means that if someone buys a Stock of a company then the person has invested in the company's equity otherwise bonds are debt securities, meaning that if someone buys a bond of a company then he has lent the funds to the company. In the event of liquidation or the company being dissolved, the shareholder will get the final stock after the company's assets are sold, while the bondholders will be given top priority on the sale of those assets ${ }^{5}$. Bonds are principally long-term debts due to the average maturity of 5 years and above.

${ }^{2}$ M. Irsan Nasaruddin dan Indra Surya, Aspek Hukum Pasar Modal Indonesia, (Jakarta :Prenada Media, 2004), page 10.

${ }^{3}$ M. Paulus Situmorang, Pengantar Pasar Modal, (Jakarta :Mitra Wacana Media, 2008), page 1

${ }^{4} \mathrm{M}$. Irsan Nasaruddin dan Indra Surya, Loc.cit, page 10.

${ }^{55}$ Hendy M. Fakhruddin, Tanya Jawab Pasar Modal, Gramedia 2008, page 50 
When compared, the Stock is valued as an investment instrument that has a much higher risk than the bond, because the value of the Stock has a very high fluctuation rate (the Stock at the opening hour of the Stockexchange with closing hours has a big enough probability to have different values). It is not only caused by influenced of the company itself but also many other market factors that determine the fluctuation of the value of the Stock itself, while the bonds have relatively low fluctuations.

Bonds are offered to the public through an Initial Public Offering. The party conducting the public offering of the bond is called the issuer. Bond issuers are referred to as debtors or who receive debt, while investors are creditors or debtors and bondholders. Bonds are classified into long-term debt, so in the long term, various possibilities can occur to the issuer of bonds or issuers, for example the company's business has decreased so that the loss and eventually the company went bankrupt or liquidated, and other things that never Allegedly before such as the economic crisis, natural disasters and so forth. Therefore in investment investors should be careful, this is because in every interaction there must be risks that arise, therefore investors should be able to analyze risks and minimize the possibility of existing risks, one of them by looking at the ratings given in bonds Published. ${ }^{6}$

A society with a conservative principle that prefers fixed income, then bonds are an option for investing as people with retirement needs. Benefits of interest or coupon given bonds tend to remain. By investing in fixed income instruments, community pension funds will be safer. In addition, the public views bonds as one of the underlying alternatives of public companies or government institutions issuing bonds as an

${ }^{6}$ Jusuf Anwar, Op.cit, page 11 
alternative to medium and long term financing such as business expansion, new machinery purchase, new investment or infrastructure development financing, as bond interest rates are lower than the interest rate Bank loans, while the investor side also benefited because it can provide a higher rate of return of bank deposits ${ }^{7}$. In Indonesia, bonds are traded on the Indonesia StockExchange. Indonesian bonds according to ADB (Asian Development Bank) show the best performance in Asia throughout $2013 .^{8}$

Investments in bonds in Indonesia are no longer promising because there have been so many cases of default and losses, especially for investors. Cases of default that began to appear, such as at PT. Mobile-8 Telecom Tbk., Which failed to pay the bond coupon, due March 2013 and declared a default of Rp. 675 Bilion, Bakrie Telecom, which issued bonds amounting to Rp. 3.8 T, with unpaid coupon was Rp. 218 Bilion, due May 2015, until BerlianLaju Tanker company and its subsidiary that issued bonds amounting to Rp. 421Bilion, with due date in February 2012 and is declared a default. This is an ongoing problem in the Indonesian economy and is becoming serious as it can lower the wheels of the economy, especially in the capital market.

The default cases indicate that some companies have defaulted on bondholders' investors by not paying principal and/or interest on corporate bonds pursuant to the agreed and pre-agreed agreements. Companies that have failed to pay can not pay interest on corporate bonds may have 2 (two) problems ie companies temporarily do not

\footnotetext{
${ }^{7}$ Edward, 2007. Analisis Faktor-Faktor Yang Berpengaruh Terhadap Perubahan Harga Obligasi, Universitas Diponogoro, Semarang

${ }^{8}$ Azis, Iwan Jaya. 2013. ADB: Pasar Obligasi Korporasi Indonesia Tertinggi di Asia Timur, http://www.neraca.co.id/article/29266/ADB-Menilai-Pasar-Obligasi-Korporasi-IndonesiaTertinggi. Diunduh tanggal 6 April 2016
} 
have cash to pay principal and / or interest bonds company or company is no longer able to pay principal and / or Interest on the bonds of the company.

The default case by issuers of corporate bonds is very detrimental to investors of bondholders, contractual relationships of parties in the bond treaty thus does not reflect a relationship based on justice. In essence contractual relations can not be released in relation to the issue of justice. A contract as recourse brings the interests of one party to another creates a fair exchange of interests. In contractual between bond issuer and investor bond holder in essence must be based on basic principles of contract law and theory of justice as base in contracting.

Article 8 paragraphs 2 and 3 of Law no. 24 of 2002 concerning Sovereign Debt Instruments stating Paragraph (2) The Government is required to pay interest and principal on every Sovereign Debt Securities at maturity. Paragraph (3) the funds to pay interest and principal as referred to in paragraph (2) shall be provided in the State Revenue and Expenditure Budget annually until the end of the obligation. It has already shown legal certainty for investors who will invest in state bonds ${ }^{9}$. However, investment in private or corporate bonds is not adequate. Basically the difference in Stock and bond trading lies in the trustee as a third party bridging between investors and issuers. And in its trade there must be a trustee contract in accordance with Article 52 of Law no. 8 of 1995 concerning the Capital Market stating that the issuer and trustee are obliged to make a trustee

${ }^{9}$ Elvira Fitriyani Pakpahan, ORI dalam Perspektif Hukum di Indoneisia, Medan: La Tansa Pers, 2010, page 9. 
contract in accordance with the provisions made by Bapepam(Capital Market Supervisory Agency).

The interesting thing to note is the sound of Item 4 of Rule Number VI.C.4 In order to protect and represent the rights of holders of Securities is debt, the Trustee is obliged to make a Trustee Contract with the Issuer which contains at least: $a$. The identity of the parties, b. Principal Debts, c. Maturity of the Principal Debt, d. Interest, e. Warranties (if any), and more. This Bapepam(Capital Market Supervisory Agency)decision is deemed not to provide legal certainty to investors because making the guarantee points is not a requirement. Whereas in the credit clearly stated elements of credit one of which is a guarantee. Debt has a vulnerable element of time, and does not rule out new things will happen in the presence of such vulnerable time bankrupt companies so unable to pay interest and bond principal. Surely it becomes anxiety for investors because of the absence of legal certainty.

The purpose of this study is to analyze and find the implementation and weaknesses in the arrangement of bonds in the Capital Market Indonesia based on the value of justice. This research is expected to be used as a step to make other policies on bonds by analyzing from all sides. In addition, it is expected that the results of this study can be used by the community to start thinking about the legality and safety aspects of investments invested so far.

This research used constructivism (interpretative) paradigm. The paradigm of constructivism is a paradigm that tries to see that the truth of a legal reality is relative, applicable in the specific context considered relevant by social actors. The reality of law is a diverse multiple realities, based on individual social experience because it is a mental 
construct of man, so the research undertaken emphasizes empathy and dialectical interaction between researchers and those studied to reconstruct the reality of law through qualitative methods ${ }^{10}$. This is kind of descriptive analytical research. This type of descriptive analytical research aims to find out a new knowledge that previously did not exist in this case that want to be found is the full legal certainty and justice that has been in relation to the arrangement of bonds in the capital market that has not fulfilled the sense of justice.

\section{B. Discussion}

\section{Implementation of bond arrangement in Indonesia capital market based on fairness value.}

The notion of bonds is not detail mentioned in the Capital Market Law and Banking Law. Article 1 Sub-Article 5 of the Capital Market Law only describes the meaning of securities stating "Securities are securities, namely debt instruments, commercial securities, stocks, bonds, debt certificates, collective investment contracting units, futures contracts, and derivatives Of the securities. "The definition of bonds clearly can be seen in Article 1 number 34 KMK No.1199 which mentions" Bonds are proof of debt from issuers that contain promises of interest or other promises and repayment of principal on the due date, at least 3 (three) years from the date of issuance.

Article 1 point 6 , Issuer is the party conducting the public offering. Article 1 point 30, Trustee Agent is a party representing the interests of holders of Securities that are debt, while the party is defined as a group of companies, companies, joint ventures,

\footnotetext{
${ }^{10}$ Esmi Warassih, Tanpa Tahun, Metode Penelitian Hukum, Yayasan Dewi Sartika, Semarang, page 162
} 
associations, or organized groups. Article 1 point 15 of Act Number 10 of 1998 concerning Banking states that: "Trustee is a business activity that can be performed by Commercial Bank to represent interests of holder of securities based on agreement between Commercial Bank and Issuer of the relevant securities".

The Indonesia Stock Exchange provides an understanding that the bonds are a transferable medium-term debt that contains the promise of the issuing party to pay the interest in the form of interest at a certain period and repay the principal of the debt at the appointed time to the buyer of the bonds. Some notions of bonds indicate that bonds are issued by the issuer as a proof of debt to bondholders and the issuer has an obligation to repay the debt and its interest on a regular and timely basis as previously agreed. Bonds are securities that fall into the category of securities. Bonds themselves satisfy the elements of securities, among other things, the value in the securities is equal to the value of the essential and transferable bonds. ${ }^{11}$

The basic form of the engagement of such accounts payable is a loaning agreement as set forth in article 1754 of the Civil Code which states "Borrowing is an agreement by which one party gives the other party a certain amount of goods consuming by usage, provided that The latter party shall return the same amount of the same kinds and circumstances."Article 1754 of the Civil Code explains that the indebted person must actually return his debt to the indebted party within the time period agreed by both the debtor and the creditor.

The implementation of the bonds shall be regulated in the Regulations of the Capital Market Supervisory Agency and Financial Institution (hereinafter referred to as Bapepam-LK) which has now

${ }^{11}$ Adrian Sutedi, 2009, Aspek Hukum Obligasi dan Sukuk, Jakarta, Sinar Grafika, page 29. 
merged with an agency called OJK Financial Services Authority. The function of Bapepam-LK in Indonesia has ended in December 2012 and the duties and roles of Bapepam-LK have been effectively continued by OJK in January 2013. Bapepam-LK's regulation on capital market implementation, especially bonds, is still valid even though it has merged with OJK.

There are no capital market regulations and financial institutions that will change after the transition of Bapepam-LK to OJK or during the transition period. ${ }^{12}$ The rules are substantially the same, the changing only in the name of the issuing agency. ${ }^{13}$ Regulations on the implementation of capital market especially regarding bonds are also regulated in the Indonesia Stock Exchange Regulation. The regulation on Bapepam-LK implementation and the Indonesian Stock Exchange Regulation concerning bonds concernon the process of bond registration, bond trading, operation, inspection, sanction and suspension.

Bapepam-LK is an abbreviation of the Capital Market Supervisory Agency and Financial Institution. In Article 3 paragraph (1) of Capital Market Law, Bapepam-LK's duty is to conduct guidance, arrangement, daily supervision of capital market activities in Indonesia. The authority of Bapepam-LK as a whole is contained in Article 5 of the Capital Market Law. Currently the duties and authorities of Bapepam-LK are replaced by an agency called OJK. The function of Bapepam-LK in Indonesia has ended in December 2012 and the duties and roles of Bapepam-LK have been effectively continued by OJK in January 2013. Bapepam-LK's regulation on capital market implementation, especially bonds, is still

\footnotetext{
${ }^{12} \mathrm{Ngalim}$ Sawega sebagaimana dikutip oleh Astri Kharina Bangun, "Bapepam pastikan aturan tak berubah pasca OJK", www.kontan.co.id, ${ }^{13}$ Ibid
} 
valid even though it has merged with OJK. There are no capital market regulations and financial institutions that will change after the transition of Bapepam-LK to OJK or during the transition period. ${ }^{14}$ The rules are substantially the same, changing only in the name of the issuing agency. ${ }^{15}$

Bapepam-LK was an authority that has a duty in overseeing trading activities in the capital market. In addition to supervising duties, Bapepam-LK also acts as a guard in the framework of the protection of capital market investors. The role of the guard here means that Bapepam-LK with all its authority in the field of capital markets has a great responsibility in maintaining, developing and advancing the Indonesian capital market by providing protection to capital market investors.

UUPM has provided extraordinary authority to Bapepam-LK, and the obligation to supervise, regulate, and nurture any party conducting activities in the capital market. Such powers and obligations are essentially for the protection of investors and in the long term to protect the immediate economy. These forms of protection include preventive protection in the form of rules, guidelines, guidance and direction; And forms of repressive protection in the form of examination, investigation, and imposition of sanctions.

In the context of bondholders' protection, both forms of protection are applied through the establishment of Bapepam Regulation, for example, regarding the issuer's openness in the bond prospectus proposal, the obligation to deliver the information due to important events, the obligation to submit the financial report

${ }^{14}$ Capital Market Supervisory Agency and Financial Institution 15 ibid 
periodically, and so on (Preventive). In addition, other forms of protection provided in order to protect bondholders are to conduct inspections, and investigations to issuers or trustees who are negligent on their obligations (Repressive). Or even appeal them to the court if the negligence of the issuer or trustee is due to having committed a lawless act in bad faith so that the holder of the bond is harmed.

\section{The weakness of the implementation of bond arrangement in Indonesia capital market.}

Corporate bonds are one of the high yielding investment instruments. The high yield given by issuers of bond issuers is inseparable from an investment risk. Legal protection is necessary given the risks inherent in corporate bonds at any time can harm bondholders' investors. Legal protection that can be given to investor bondholders is protection of preventive law and repressive law protection.

Preventive legal protection may be the content of the trustee agreement made by the trustee. Protection of preventive law is also provided by the government through prevention measures in accordance with the provisions of Capital Market Law and Kep. Bapepam no. 412. Repressive legal protection that can be granted to investors of bondholders one of which is a bondholder investor is given the opportunity to get his rights through a lawsuit in court. Bondholders' investors through the trustee are given an opportunity by Article 111 of the Capital Market Law to claim damages suffered to the party responsible for the loss.

Theinherent risks in corporate bonds are directly proportional to the yields offered by the issuer. Bondholders' investors need a definite legal protection if at times the risks that potentially harm their 
investment occur. The first risk is liquidity risk. Liquidity risk can occur due to the inability to sell corporate bonds in the secondary market.

The unfavorable selling of corporate bonds in the secondary market can be due to the state of the bond market. Investor bondholders may ask for additional interest if they have unscientific or difficult-to-sell corporate bonds in the secondary market. ${ }^{16}$ The addition of the bond interest rate of this company may be requested by bondholders to the issuer if it has been previously regulated in the trustee agreement. Corporate bonds become liquid if there are buyers who are always available to buy corporate bonds in the secondary market.

The second risk is the risk of interest rate fluctuations. This risk can occur primarily in corporate bonds with fixed coupon rate. The risk of interest rate fluctuations occurs due to the increase in commercial interest rates. The rate of increase in commercial interest rates can lead to a decrease in the price of corporate bonds. Increase in commercial interest rates can occur due to market movements and economic conditions of an uncertain country. The protection that can be provided to bondholders is only in the form of a preventive action. This action can be education and information notification to prospective bondholders who will buy corporate bonds.

The third risk is the risk of reinvestment. Reinvestment risk may occur in corporate bonds with low coupon rates and long maturities. Corporate bonds with low coupon rates and long maturities will lead to uncertainty in return of principal and interest payments on corporate bonds. Bondholders' investors through a trustee agreement made by the trustee may request additional bond interest rates as well as a more

${ }^{16}$ Adrian Sutedi, Op. Cit., Page 79. 
definite timeframe. This can be done by the trustee as a representative of the investor of the bondholder at the time of negotiation determines the contents of the trustee agreement. Thus, corporate bonds that have the potential to generate uncertainty in payments can be overcome.

The fourth risk is the default risk. The default risk can also be called the risk of default. The risk of default may occur because the issuer can not fulfill the obligation to pay interest on corporate bonds or loan principal to bondholders. The risk of default is due to the fact that the issuer has no funds for the time being, liquidation, disbandment or bankruptcy ${ }^{17}$. The Company may be said to have defaulted if it does not comply with the provisions in the obligation to pay the principal on the date of redemption of the principal of the bonds and / or interest on the date of bond interest payment. ${ }^{18}$

Another risk that may arise is the risk caused by the trustee. This risk may be the default of the trustee in performing his duties or in the form of loss of principal and / or interest payments due to the payment agent. Investors of bondholders harmed by the trustee may request to the trustee to hold the RUPO. Trustee who has neglected in performing his duties as trustee or as payment agent and proven to be detrimental Investors bondholders can be dismissed through RUPO.

Bondholder investors may also report to OJK if the trustee ignores the losses suffered by bondholders. OJKs that have received reports from bondholders' investors may request that the trustee or issuer to hold the RUPO. The RUPO held at the request of the OJK aims to resolve the issue of bond holders' investors and dismiss the trustee and replace it with a new trustee. It may also be made by bondholders

\footnotetext{
${ }^{17}$ Ibid.,Page 80.

${ }^{18}$ Pasal 5.1.a Prospektus Obligasi 1 Agung Podomoro Land Tahun 2011
} 
if the default of principal payment and / or interest on the bond is caused by another institution acting as a payment agent such as KSEI. Investors of bondholders may report to the trustee or OJK in the event of a bottleneck of principal and / or interest payment of bonds by KSEI and may then be requested to hold RUPO by the trustee or OJK. The RUPO is held with the objective of finalizing the payment of principal and / or interest on the bonds or to replace the payment agent.

Risk of default is the highest risk inherent in corporate bonds. Almost every year there is one to several BUMS in Indonesia that have failed to pay corporate bonds. Based on several sources, there are still many issuers who have not paid off their corporate bonds and hang the fate of bondholders' investors. Bondholder investors need both preventive and repressive legal protection to recover the principal and/or interest payments of corporate bonds issued by the issuer.

The trustee as the representative of the bondholder investor will make full efforts in carrying out his duty of representing and protecting bondholders' investors especially if there is a risk to the issuer's bonds issued by the issuer. In corporate bonds, not apart from the risks, especially default. Understanding of default can be interpreted as the inability of issuer in paying its debts to investor of bond holder as stated in number 1 letter a Decision of Chairman of Bapepam-LK No: KEP-555 / BL / 2010 About Sustainable Public Offering which mention "Failed to pay is not The fulfillment of the financial obligations of the issuer or the public company against the creditor at maturity."

Unfulfilled financial obligations in the provisions of point 1 letter a Decision of the Chairman of Bapepam-LK No: KEP-555 / BL / 2010 concerning the Sustained Public Offering when the issuer is unable to pay the principal of the debt along with interest or other liabilities to the 
creditors. The creditor in this case is a bondholder investor who issues funds to buy corporate bonds and is entitled to receive the receivables as agreed in the trustee agreement.

Failed to pay by issuers can occur because issuers issuing corporate bonds are negligent in paying corporate bond interest at the time specified in the trustee agreement. Failed to pay can also occur because the issuer does not pay the entire principal debt or principal debt along with interest on corporate bonds that have matured to investors bondholders. The definition of debt is matured in the explanation of article 2 paragraph (1) of the Bankruptcy and PKPU Law. According to the explanation of Article 2 Paragraph (1) of the Bankruptcy and PKPU Law, "Debt that has been matured and collectable" is the obligation to repay the debts that have fallen due to the accelerated time of collection as promised because of the imposition Sanction or penalty by the competent authority, or by a court decision, arbitrator, or arbitral panel.

\section{Conclusions}

Based on the results of the research on the bonds default, of course, the main problem of bond trading transaction is the contract of trustee. So the author finds a new theory that is the theory of "equilibrium agreement". The theory of the equilibrium agreement is based on achieving a balanced state. The equilibrium word on one side is limited by the will (raised by consideration or favorable circumstances), and on the other hand by the belief (of the ability to) manifest the desired result or result; Within the limits of both sides of this is achieved a positive balance. Balanced theory emphasizes the balance of the contracting parties' position is balanced. It is based on the fact that there is an imbalance of bargaining position of the parties. Although the 
agreement has put forward the principle of freedom of contract. Freedom of contract is based on the assumption that the parties to the contract have a balanced bargaining position, but in reality the parties do not always have a balanced bargaining position. The covenant is said to be balanced not only based on its ultimate purpose but equality and the same wealth of wealth and the ultimate aim of the future. So an agreement must be based on and given a charge that explains the conditions, circumstances and clearly accommodate the will of the parties in order to avoid a form of imbalance that resulted in losses on one of the parties in it. The Balanced Agreement Theory is certainly different from the 3P Scoott J. Burham theory that basing in the preparation of a contract should begin with the following thoughts:

1. Predictable, in the design and analysis of contracts a drafter should be able to predict or predict what possibilities will occur in relation to the contract.

2. Provider, ie Get ready for the possibility that will happen.

3. Protect of Law, legal protection against contracts that have been designed and analyzed so as to protect clients or business actors from the worst possible possibility of doing business.

The Balancing Theory of this Agreement puts more emphasis on the balance position of the parties because in its journey the form of imbalance is a manifestation of the absence of accepting the wishes of the parties in the agreement that it is based on the action where the existence of one of the higher parties, causing the other party can not do much Which causes the other party to accept or reject the situation. Terms of the Agreement Theory of Equilibrium in order that any exchange that culminates in a fair enrichment, can be viewed as a fair exchange then an achievement must be balanced by contra 
achievement. Reciprocal exchange is a key concept for the creation of justice which is also in accordance with the dignified justice theory of TeguhPrasetyo's idea which aims also to provide justice for all parties. Thus, the reconstruction of bond arrangement in Indonesia capital market is considered very necessary even expected immediately considering the development of bonds in the capital market is growing day by day, both from conventional and sharia bonds.

\section{References}

Abdul Ghofur Anshori, 2006 Filsafat Hukum, Gadjah Mada University Press, Yogyakarta,

Abdulkadir Muhammad, 2004, Hukumdan Penelitian Hukum, Citra Aditya Bakti, Bandung,

Achmad Ali, 2002, Keterpurukan Hukum di Indonesia: Penyebabdan Solusinya, Ghalia Indonesia, Jakarta

Bodie, Zvi., Kane, Alex., Marcus alan. 2011 Investment and Portofolio Management. Global Edition. McGraw-Hill,

Bryan A. Garner, 2001. Black's Law Dictionary, 2nd Pocket Edition, St. Paul Minn: West Publishing Co.,

B. De Smalen, Bursa Efek, 1997. Perusahaan Efek dan Lalu Lintas Efek, Jakarta : PT. Pradnya Paramita,

B.N. Marbun, 1996. Kamus Politik, Pustaka Sinar Harapan, Jakarta,

Carl Joachim Friedrich. 2010. Filsafat Hukum: Perspektif Historis. Bandung: Penerbit Nusa Media,

Dahlan Siamat, 2005. Manajemen Lembaga Keuangan (Kebijakan Moneter dan Perbankan), Lembaga Penerbit Fakultas Ekonomi Universitas Indonesia. Jakarta

Dedy N. Hidayat, 2003. Paradigma dan Metodologi Penelitian Sosial Empirik Klasik, Departemen Ilmu Komunikasi FISIP Universitas Indonesia, Jakarta,

Elvira Fitriyani Pakpahan, 2010. ORI dalam Perspektif Hukum di Indonesia, La Tansa Pers. Medan.

Edgar Bodenheimer, 1962. Yurisprudence: The philosophy and Method of the Law, Cambriage, Massachusetts,

Edilius dan Sudarsono, 1994. Kamus Ekonomi Uang dan Bank, Jakarta :Rineka Cipta,

Efran Helmi Juni. 2012. Filsafat Hukum. Halaman: CV Pustaka Setia. Bandung. 
Fredi R. Saragih, "Prosedur dan Tata Cara Penerbitan Instrumen Utang di Indonesia" PPH Newsletter.No. 43/XI/Desember/2000

"Frequently Asked Questions about Trusts",hlm. 4, http://www. asaprotection.com/faq.htm\#WHERE\%20DO\%20TRUST S\%20COME\%20FROM?, 23 Juni 2005, (FAQ1). Lihatjuga Gwenn H. Wycoff, "What is Common Law Trust?", hlm. 1, http://www.socal.com.prints/574.html, 30 Juni 2016

"Frequently Asked Question About Trusts", http://wWw. wealth4freedom.com/truth/TBA/TrustsFAQS.htm, 4 Juli 2016

Gunawan Widjaja, "Reksa Dana Kontrak Investasi Kolektif sebagai Bentuk Hukum dan Bisnis Modern dari Persekutuan", Newsletter No. 58, (September, 2004

Hatta Muhammad, Pelaksanaan Undang-Undang Dasar 1945 Pasal 33, dalam Panitia Seminar Penjabaran Pasal 33 UUD 1945, Penjabaran Pasal 33 Undang-Undang Dasar 1945, Penerbit Mutiara, Jakarta, 1977

Herdy, Damena.2013."Analisis Pengaruh Coupon (Bunga Obligasi), Jangka Waktu Jatuh Tempo, dan Likuiditas Obligasi Terhadap Tingkat Perubahan Harga Obligasi yang Terdaftar di Bursa Efek Indonesia".

Herwidayatmo, "Kesiapan Bapepam sebagai Regulator dalam Perdagangan Efeksecara Elektronik(E-Commerce)", Makalah dalam seminar sehari Pasar Modal Kesiapan Pelaku Pasar Modal dengan diimplementasikannya Scripless Trading Menuju Era On Line Trading, Jakarta, 1 November 2000

Iswahjudi A. Karim\&Mirza A. Karim, "Perlunya Peraturan Perundangundangan Mengenai Pasar Modal Berdasarkan Prinsip Syariah", September 2005 